\title{
ANALISIS NILAI RISIKO PORTOFOLIO OPTIMUM PADA REKSADANA CAMPURAN DENGAN PENDEKATAN EWMA
}

\author{
Noviana Pratiwi \\ Sains Terapan, IST AKPRIND Yogyakarta \\ email: novianapratiwi@akprind.ac.id
}

\begin{abstract}
Value at Risk (VaR) is one of the risk measurement techniques and is considered a standard method of measuring risk. EWMA is one method to find standard deviation value of Conditional Variance which used to calculate the VaR. Investors use VaR to determine risk level. VaR defined as the estimated loss of portofolio with a certain level of confidence. Portfolio composed of several mixed mutual funds. Of the four mutual funds only two mutual funds that can be arranged to get an optimum portfolio, 20\% of mutual funds Kresna Flexima and 80\% Nikko BUMN Plus. Portfolio VaR is calculated by EWMA method because it found the existence of conditional Variance. With 95\% level of trust and decay factor in accordance with the proposed risk metrics of 0.94 for daily data then obtained the VaR value of 0.26221011 . This means that the maximum losses that may be received by investors amounted to $26.22 \%$ if investors invest in assets recommended by the optimal portfolio. This level of risk will be used by investors to control the investment risk.
\end{abstract}

Keyword: VaR, EWMA, Portofolio Optimum, Reksadana

\section{PENDAHULUAN}

Menurut Undang-Undang no.8 tentang Pasar Modal, reksadana adalah wadah yang dipergunakan untuk menghimpun dana masyarakat pemodal untuk selanjutnya diinvestasikan dalam portofolio efek oleh manajer investasi. Reksadana sangat cocok bagi investor yang tidak punya waktu, pengetahuan serta pengalaman yang cukup untuk aktif mengelola investasi investor karena dalam reksadana, investasi yang diberikan investor akan dikelola oleh pihak ahli yaitu menejer investasi. Modal yang rendah juga merupakan alasan kenapa investor mulai melirik reksadana. Melalui reksadana, investor bisa membeli saham sekaligus obligasi dengan modal yang rendah karena salah satu filosofi reksadana adalah dimana dana masyarakat dikumpulkan untuk diinvestasikan oleh Manajer investasi ke dalam instrumen yang aksesnya relatif sulit (portal reksadana). Manajer investasi akan berperan sebagai pengelola investasi yang terkumpul dari sekian banyak investor untuk diinvestadikan ke dalam portofolio efek seperti T/D, SBI, Obligasi dan saham.

Harapan investor terhadap investasinya adalah memperoleh return sebesar-besarnya dengan risiko tertentu. Risiko merupakan besarnya penyimpangan antara tingkat pengembalian yang diharapkan (expected return) dengan tingkat pengembalian aktual (actual return) (Hikmah, 2015). Risiko pasar (market risk) merupakan suatu risiko yang timbul karena menurunnya nilai suatu investasi karena pergerakan pada faktorfaktor pasar (Rosadi, 2009). Risiko sering dihubungkan dengan volatilitas atau penyimpangan deviasi dari hasil investasi yang akan diterima dengan keuntungan yang diharapkan. Volatilitas merupakan besarnya harga fluktuatif dari sebuah aset. Semakin besar volatilitas aset, maka semakin besar kemungkinan mengalami kerugian.

Volatilitas harga dengan pergerakan harga aset-aset keuangan di pasar modalpun menjadi fokus atas tersedianya risiko pasar ini (Laila, 2010). Pratiwi, 2015 mengemukakan untuk mengontrol dan 
mengurangi risiko pasar yang terjadi, para pelaku pasar dapat melakukan pengukuran volatilitas atau tingkat risiko dari aset-aset keuangan yang mereka miliki. Ukuran risiko inilah yang selanjutnya digunakan untuk mengendalikan atau mengelola risiko dalam manajemen risiko. Value at Risk (VaR) merupakan salah satu alat untuk mengukur risiko pasar yang ada. Fardiansyah (2016) menyatakan pengukuran risiko dengan Value at Risk (VaR) saat ini sangat popular digunakan secara luas oleh industri keuangan di seluruh dunia. Pemerintah, dalam hal ini peraturan Bank Indonesia (BB) $\mathrm{Np} .5 / 8 / / \mathrm{PBI} / 2003$ tentang penerapan pengelolaan risiko bagi perbankan pada tahun 2008 dan surat edaran No.5/21/DPNP tanggal 29 September 2003 tentang penerapan metode VAR, menyebabkan pengembangan konsep VAR pada institusi perbankan berkembang pesat.

Value at Risk (VaR) merupakan salah satu alat atau teknik untuk mengetahui kerugian terburuk yang mungkin terjadi sebagai akibat dari kepemilikan suatu sekuritas atau portofolio selama periode waktu tertentu, dengan tingkat spesifikasi tertentu yang dikenal sebagai tingkat kepercayaan (confidence level). Secara sederhana, VaR ingin menjawab pertanyaan "seberapa besar (dalam persen atau sejumlah uang tertentu) investor dapat merugi selama waktu investasi $t$ dengan tingkat kepercayaan $(1-\alpha)$ ". Berdasarkan pertanyaan tersebut, dapat dilihat adanya tiga variabel yang penting yaitu besar kerugian, periode waktu dan besar tingkat kepercayaan (Pratiwi, 2011). Aspek terpenting dalam perhitungan $\mathrm{VaR}$ adalah menentukan jenis metodologi dan asumsi yang sesuai dengan distribusi return. Penerapan metode dan asumsi yang tepat akan menghasilkan perhitungan VaR yang akurat untuk digunakan sebagai ukuran risiko (Fuss, 2007). Model Exponentially
Weighted Moving Average (EWMA) adalah salah satu model yang digunakan dalam mengestimasi besarnya volatilitas dalam satu periode waktu tertentu baik harian, bulanan maupun tahunan. Model ini dikembangkan oleh JP Morgan, 1995.

Metode EWMA ini didasarkan pada bobot yang berbeda, pada return yang terdahulu diberikan bobot yang lebih kecil sesuai dengan posisi masing-masing return dalam satu set data, dan untuk return sekarang menerima bobot yang lebih tinggi. Dalam metode EWMA tidak ada perubahan volatilias secara mendadak ketika terjadi extreem event, seperti bobot pada observasi yang menurun secara eksponensial. Pada penelitian ini akan dihitung VaR dengan pendekatan EWMA pada portofolio reksadana di Indonesia dengan tujuan memberikan gambaran mengenai profil risiko pasar bagi investor reksadana di Indonesia. Reksadana yang akan dicari VaR nya adalah beberapa reksadana campuran.

Menurut Astria (2015), dinamika return aset sepanjang 2011-2014, reksa dana campuran memiliki prospek yang bagus. Reksadana campuran memiliki keunggulan bisa melakukan perpindahan investasi ke aset yang potensial memberikan return lebih tinggi dalam periode tertentu (alokasi aset taktis). Dengan alokasi aset taktis yang tepat, reksadana campuran dinilai bisa menghasilkan return melebihi IHSG dengan risiko yang lebih rendah dari IHSG. Indonesia mempunyai beberapa reksadana campuran dengan return melampaui pencapaian IHSG sepanjang 3 tahun terakhir (periode 19 Januari 2012- 19 Januari 2015). Sesuai urutan, produk reksadana tersebut adalah Kresna Flexima besutan PT Kresna Asset Management, Pratama berimbang besutan PT Pratama Capital Asset Management, Nikko BUMN Plus yang dikelola PT Nikko Asset Management dan 
SAM Syariah Berimbang milik PT Samuel Asset Management.

Berdasarkan uraian diatas maka tujuan dari penelitian ini adalah untuk mengetahui seberapa besar potensi kerugian yang akan dihadapi investor selama melakukan investasi di instrumen reksadana campuran dihitung dengan metode VaR pendekatan EWMA.

\section{METODE PENELITIAN}

Penelitian ini akan membahas tentang penerapan metode EWMA dalam mencari tingkat risiko suatu investasi. Dalam penelitian ini akan mencari tingkat risiko portofolio yang terdiri dari empat reksadana campuran yang dipilih berdasarkan kinerjanya selama tiga tahun. Data yang akan diteliti diambil dari data sekunder dari web kontan dengan link www.pusatdata.kontan.co.id. Penelitian ini dilaksanakan mulai dari bulan April sampai dengan bulan September 2016. Penelitian ini terbagi menjadi tiga tahap yaitu tahap persiapan penelitian, tahap pelaksanaan penelitian dan tahap laporan.

Populasi penelitian ini adalah nilai NAB dari reksadana Campuran di semua reksadana yang dijual di pasar Modal Indonesia. Sampel dalam penelitian ini adalah nilai NAB dari empat reksadana Campuran di Indonesia dengan return yang melampaui pencapaian IHSG sepanjang tiga tahun terakhir (periode 19 Januari 2012 - 19 Januari 2015). Produk reksadana tersebut adalah Kresna Flexima besutan PT Kresna Asset Management, Pratama berimbang besutan PT Pratama Capital Asset Management, Nikko BUMN Plus yang dikelola PT Nikko Asset Management dan SAM Syariah Berimbang milik PT Samuel Asset Management

Langkah-langkah penelitiannya secara umum adalah, memilih reksadana campuran dengan return yang melebihi IHSG selama tiga tahun terakhir. Setelah data diperoleh kemudian dicari return. Return merupakan tingkat pengembalian keseluruhan dari suatu investasi dalam suatu periode. Besarnya return dapat dicari dengan rumus

$$
r_{t}=\frac{P_{t}-P_{t-1}}{P_{t-1}}
$$

Dengan $P_{t}$ adalah harga aset pada saat $\mathrm{t}$ dan $P_{t-1}$ adalah harga aset pada saat t-1

Nilai return yang diperoleh kemudian digunakan untuk mencari standar deviasi yang selanjutnya data return diuji stasioneritasnya dengan uji Argumented Dicky Fuller (ADF). Portofolio yang optimum kemuadian dibentuk dilakukan dua pengujian, Uji distribusi Normal dan Uji Heteroskedastisitas portofolio untuk menentukan volatilitas dan tingkat keyakinan guna mencari tingkat resiko. Jika distribusi Normal terpenuhi, maka dipakai nilai $\alpha$ sesuai tabel Z. Namun jika didapat bukan normal, maka nilai $\alpha$ sesuai dengan pendekatan Cornish Fisher Expansion. Untuk Uji heteroskedastis, jika terpenuhi maka $\sigma$ dihitung dengan pendekatan EWMA sedangkan jika data homoskedastis maka $\sigma$ dihitung dengan menggunakan rumus dasar standar deviasi. Selanjutnya nilai VaR dihitung dengan persamaan pendekatan Exponentially Weight Moving Average (EWMA). Nilai VaR tersebut kemudian divalidasi dengan uji Kupiec.

\subsection{RiskMetrics}

RiskMetrics, sepengangkat alat berupa dokumen yang digunakan untuk mengestimaasi keyakinan dari tingkat risiko. Dengan bantuan dari dokumen ini diharapkan pengguna bisa memperkirakan risiko pasar dala portofolio. Dalam pembahasan disini RiskMetrics digunakan untuk membantu menentukan nilai $\lambda$ optimal yang digunakan dalam pencarian VaR dengan metode EWMA. Berdasarkan dokumen RiskMetrics, 
nilai $\lambda$ yang optimal didapatkan dengan meminimalisasikan selisih rata-rata kuadrat antara estimasi variansinya dengan return kuadrat untuk setiap harinya. Pada RiskMetrics Technical dokument (Morgan, 1995) telah diusulkan bahwa rata-rata $\lambda=$ 0,94 menghasilkan peramalan yang saangat baik untuk estimasi volatilitas harian. Sedangkan $\lambda=0,97$ baik digunakan dalam estimasi satu bulan.

\subsection{Portofolio Optimal}

Portofolio adalah sekumpulan aset berupa investasi yang dimiliki oleh investor (Fitriyani 2015). Tujuan utama portofolio adalah untuk mengurangi tingkat resiko yang ada dengan cara diversifikasi aset yang dimiliki investor. Untuk mendapatkan tingkat kerugian yang paling minimal dan mendapatkan return yang maksimal maka perlu dilakukan pengoptimalan portofolio. Portofolio dibentuk menggunakan metode Markowitz. Metode markowitz membentuk sel efisien dan portofolio opttimalnya dengan pendekatan kuantitatif yang menghubungkan resiko yang diukur dengan deviasi standar atau varian dengan return ekspektasinya atau rata-rata returnnya (Hartono, 2014).

Model Markowitz menggunakan asumsiasumsi sebagai berikut :

1. Waktu yang digunakan hanya satu periode

2. Tidak ada biaya transaksi

3. Preferensi investor hanya didasarkan pada return ekspektasian dan risiko dari portofolio

4. Tidak ada pinjaman dan simpanan bebas risiko.

5. Kendalanya adalah proporsi dari masing-masing aktiva tidak boleh bernilai negatif.

\subsection{Exponentially Weight Moving Average (EWMA)}

Model EWMA merupakan salah satu model yang digunakan dalam mengestimasi besarnya volatilitas dalam satu periode waktu tertentu baik harian, bulanan maupun tahunan. Dalam dunia finansial, volatilitas merupakan ukuran untuk variasi harga dari instrumen finansial dari waktu ke waktu (Pratiwi, 2011). Watsham (1997), menyebutkan bahwa volatilitas yang konstan disebut homoscedastis dan volatilitas yang tidak konstan disebut heteroscedastis. Saat ini, metode penghitungan volatilitas heteroscedastis banyak dikembangkan oleh para ahli manajemen risiko.

Menurut Down (2002), metode yang digunakan saat ini adalah metode Exponentially Weighted Moving Average (EWMA) yang dikembangkan J.P. Morgan. Metode ini melakukan estimasi volatilitas dengan memberikan bobot pengaruh lebih besar terhadap volatilitas data terbaru. persamaan EWMA yang digunakan. Dari Jorion (2001) yang mengutip J.P Morgan, diketahui Metode EWMA didasarkan pada bobot yang berbeda, pada return yang terdahulu diberikan bobot yang lebih kecil sesuai dengan posisi masing-masing return dalam satu set data, dan untuk return sekarang menerima bobot yang lebih tinggi. Dengan kata lain pendekatan EWMA mengasumsikan proyeksi yang akan datang (esok hari) dipengaruhi oleh data aktual hari ini dan data masa lampau. Metode EWMA lebih cepat bereaksi terhadap shock volatilitas dan metode ini tidak ada perubahan volatilias secara mendadak ketika terjadi extreem event. Suatu EWMA periode dari deret waktu $X_{t}$ didefinisikan sebagai berikut: 


$$
\frac{X_{t-1}+\lambda X_{t-2}+\lambda^{2} X_{t-3}+\ldots+\lambda^{n-1} X_{t-n}}{1+\lambda+\lambda^{2}+\ldots+\lambda^{n-1}}, 0<\lambda<1
$$

Untuk $n \rightarrow \infty$ penyebut akan konvergen ke $\frac{1}{1-\lambda}$ sehingga EWMA tak hingga dapat ditulis

$$
\sigma_{t}^{2}=(1-\lambda) \sum_{i=1}^{T} \lambda^{i-1} r_{t-i}^{2}
$$

Dengan

$\sigma_{t}^{2}=$ varian dari data imbal hasil

$r_{t-1}=$ return pada saat ke $\mathrm{t}-1$

$\lambda=$ parameter (decay factor)

Estimasi volatilitas dari EWMA adalah

$$
\sigma_{t}=\sqrt{(1-\lambda) \sum_{i=1}^{T} \lambda^{i-1} r_{t-i}^{2}}
$$

$\lambda$ adalah decay factor atau faktor perusak yang bernilai konstan besarnya antara 0 dan 1. Untuk $\mathrm{t}=1$ maka $\lambda$ pangkat $0, \mathrm{t}=2$ maka $\lambda$ pangkat 1 , jika $\mathrm{t}=3$ vmaka $\lambda$ pangkat 2 dan seterusnya, jika $\mathrm{t}$ besar, maka pangkatnya juga besar sehingga jika t lebih banyak maka bobotnya akan lebih kecil.

Dari persamaan (2.3)

$$
\begin{aligned}
& \sigma_{t}^{2}=(1-\lambda) \sum_{i=1}^{T} \lambda^{i-1} r_{t-i}^{2} \\
& \sigma_{t}^{2}=(1-\lambda)(r_{t-1}^{2}+\underbrace{\lambda r_{t-2}^{2}+\lambda^{2} r_{t-3}^{2}+\ldots+\lambda^{T-2} r_{t-T+1}^{2}+\lambda^{T-1} r_{t-T}^{2}}_{A})
\end{aligned}
$$

persamaan (2.4)

Untuk volatilitas sehari sebelumnya siperoleh

$$
\begin{aligned}
& \sigma_{t-1}{ }^{2}=(1-\lambda) \sum_{i=1}^{T} \lambda^{i-1} r_{t-1-i}^{2} \\
& \lambda \sigma_{t-1}{ }^{2}=(1-\lambda) \sum_{i=1}^{T} \lambda^{i} r_{t-1-i}^{2} \\
& \lambda \sigma_{t-1}{ }^{2}=(1-\lambda)(\underbrace{\lambda r_{t-2}^{2}+\lambda^{2} r_{t-3}^{2}+\lambda^{3} r_{t-4}^{2}+\ldots+\lambda^{T-1} r_{t-T}^{2}}_{A}+\lambda^{T} r_{t-1-T}^{2})
\end{aligned}
$$

$$
\begin{aligned}
& \frac{\lambda \sigma_{t-1}{ }^{2}}{(1-\lambda)}=A+\lambda^{T} r_{t-1-T}^{2} \\
& A=\frac{\lambda \sigma_{t-1}{ }^{2}}{(1-\lambda)}-\lambda^{T} r_{t-1-T}^{2}
\end{aligned}
$$

Substitusikan A ke persamaan (2.4)

$$
\begin{aligned}
& \sigma_{t}^{2}=(1-\lambda)\left(r_{t-1}^{2}+\frac{\lambda \sigma_{t-1}^{2}}{(1-\lambda)}-\lambda^{T} r_{t-1-T}^{2}\right) \\
& \sigma_{t}^{2}=(1-\lambda) r_{t-1}^{2}+\lambda \sigma_{t-1}^{2}-(1-\lambda) \lambda^{T} r_{t-1-T}^{2}
\end{aligned}
$$

Jika $\mathrm{T}$ mendekati tak hingga, maka $\lambda$ mendekati nol. Dan volatilitasnya menjadi

$$
\sigma_{t}^{2}=\lambda \sigma_{t-1}^{2}+(1-\lambda) r_{t-1}^{2}
$$

Volatilitas dari periode ke $t$ akan diperoleh dari return pada hari sebelumnya dan estimasi volatilitas sebelumnya. Jadi dalam metode EWMA dapat diketahui estimasi volatilitas harian dari data return harian yang diketahui. Jika $\lambda$ bernilai besar maka bobot akan turun secara pelan pelan dan jika $\lambda$ bernilai rendah maka bobot akan turun secara cepat. RiskMetrics-Technical Document menyarankan pengambilan $\lambda$ sebesar 0,94 untuk return harian.

Pada persamaan (2.5) terdapat dua persamaan yaitu $\lambda \sigma_{t-1}{ }^{2}$ menunjukkan persistence in volatility yang diartikan apabila periode yang lalu volatilitas tinggi maka akan tetap tinggi untuk hari ini. Bagian kedua $(1-\lambda) r_{t-1}{ }^{2}$ menunjukkan intensitas reaksi terhadap volatilitas karena kondisi pasar. Bila $\lambda$ semakin rendah, maka valatilitas semakin reaktif terhadap informasi pasar pada return periode kmarin.

\subsection{Value at Risk (VaR)}

Value at Risk merupakan kerugian maksimum yang bisa saja terjadi pada periode waktu tertentu dengan kemungkinan yang pasti. Perhitungan vaR untuk asset menggunakan rumus dari Jorion 2001 yaitu

$$
\operatorname{VaR}=\alpha \cdot \sigma_{p} \cdot W
$$


Dengan $\alpha \quad$ tingkat kepercayaan

$\sigma_{p} \quad=$ standar deviasi portofolio

$\mathrm{W} \quad=$ nilai posisi aset

VaR memiliki hubungan yang erat dengan ARCH-GARCH dimana sering digunakan jika terjadi ketidakhomogenan ragam dari data return dan estimasi volatilitasnya. Sedangkan penduga ragam biasa tidak bisa melakukan pendugaan ragam jika asumsi homoskedastisitasnya tidak terpenuhi. Jika hal tersebut terjadi maka perhitungan VaR untuk asumsi homoskedastisitasnya tidak terpenuhi menggunakan penduga ragam dengan metode EWMA.

Selain Ragam, tingkat kepercayaan juga diperlukan untuk menghitung VaR. VaR dengan distribusi normal akan dicari dengan menggunakan nilai $\alpha$ yang sudah ditetapkan sebesar nilai $Z$ untuk untuk tingkat kepercayaan tertentu. Sedangkan untuk data yang tidak berdistribusi normal, maka nilai $\alpha$ dikoreksi dengan pendekatan Cornish Fisher Expansion. Dalam pendekatan ini memperhatikan kemiringan (skewness) dan kurtosis, nilai $\alpha$ diperoleh dengan rumus :

$$
\begin{gathered}
Z=\left(z_{c}+\frac{1}{6}\left(z_{c}{ }^{2}-1\right) S+\frac{1}{24}\left(z_{c}{ }^{3}-3 z_{c}\right) K-\right. \\
\left.\frac{1}{36}\left(2 z_{c}{ }^{3}-5 z_{c}\right) S^{2}\right)
\end{gathered}
$$

Dengan $\mu$ dan $\sigma$ adalah mean dan standar deviasi, $\mathrm{S}$ adalah skewness, $\mathrm{K}$ kurtosis, $z_{c}$ kuantil dari distribusi dan $\mathrm{Z}$ adalah asimtot Cornish- Fisher untuk kuantil distribusi tidak normal.

\subsection{Component VaR (CvaR)}

VaR Komponen adalah kontribusi risiko masing-masing komponen terhadap risiko portofolio. Jumlahan dari masing-masing CvaR ini akan sama dengan nilai VaR. Nilai CvaR ini akan sangat membantu investor dalam pengelolaan risikonya. Dalam penelitiannya, Buchdadi (2008) berdasarkan pernyataan Jorion, menyebutkan bahwa CvaR menunjukkan berapakah nilai VaR portofolio akan berubah jika komponen tersebut dihilangkan dari portofolio. Jorion (2001) menyebutkan bahwa perhitungan CVaR digunakan persamaan :

$$
C V a R_{i}=\alpha \sigma_{i} w_{i} W \rho_{i}=V A R_{i} \rho_{i}
$$

Reksadana pembentuk portofolio nantinya akan dihitung komponen portofolionya $(\mathrm{CVaR})$ dengan rumus diatas. Dan selanjutnya dilakukan uji validasi dengan uji kupiec.

\subsection{Backtesting}

Backtesting adalah istilah untuk pengecekan apakah model yang kita gunakan sudah sesuai dengan realitas yang ada. Jadi Value at Risk yang telah diperoleh tidak langsung diterima melainkan harus diuji terlebih dahulu apakah model perhitungan yang telah dibentuk memenuhi uji validasi atau tidak. Melalui backtesting bisa diketahui model mana yang memiliki tingkat validasi terbaik. Metode Backtesting yang akan digunakan adalah uji kupiec. Hipotesis dari uji kupic adalah

$$
\begin{aligned}
& H_{0}: P(x) \leq P^{*} \\
& H_{1}: P(x)>P^{*}
\end{aligned}
$$

Probabilitas dari banyaknya data yang melebihi nilai VaR akan kurang dari $P^{*}$ yang merupakan batas toleransi besarnya penyimpangan dari VaR yang nilainya ditentukan atau sebesar 1 dikurangi interval konvidensi. Jumlah x merupakan jumlah data observasi return yang melebihi nilai VaR mengikuti distribusi binomial. Dengan $n$ jumlah observasi statistik hitung adalah

$$
\hat{\alpha}=1-\sum_{i=0}^{x}\left(\begin{array}{c}
n \\
i
\end{array}\right)\left(P^{*}\right)^{i}\left(1-P^{*}\right)^{n-i}
$$


$H_{0}$ ditolak jika $\hat{\alpha}$ kurang dari tingkat signifikan $\alpha$. Jika $\alpha$ lebih dari tingkat signifikan maka $H_{0}$ diterima dan dapat dikatakan bahwa model Value at Risk baik digunakan.

\section{HASIL DAN PEMBAHASAN}

Perhitungan VaR yang akan dibahas dalam BAB ini adalah portofolio optimal yang nantinya akan dibentuk untuk mengetahui seberapa besar tingkat resiko yang mungkin terjadi sehingga investor bisa menentukan langkah apa untuk menghadapi resiko tersebut. Portofolio optimum dibentuk dari beberapa reksadana campuran yang dalam tida tahun terakhir mendapat return yang melampaui pencapaian IHSG sepanjang 3 tahun terakhir (periode 19 Januari 2012 19 Januari) (Astria, 2015). Produk reksadana tersebut adalah Kresna Flexima besutan PT Kresna Asset Management, Pratama berimbang besutan PT Pratama Capital Asset Management, Nikko BUMN Plus yang dikelola PT Nikko Asset Management dan SAM Syariah Berimbang milik PT Samuel Asset Management.

Data yang dianalisis diambil dari www.pusatdata.kontan.co.id selama periode 1 Januari sampai dengan 31 Desember 2015. Data yang diperoleh kemudian diolah untuk selanjutnya dilakukan analisis. Nilai NAB dari masing-masing produk reksadana campuran tersebut dicari nilai return nya dan untuk selanjutnya dicari standar deviasi standar masing-masing reksadana yang akan disajikan dalam tabel berikut :

\section{Uji stasioneritas}

Setelah standar deviasi diperoleh, langkah selanjutnya adalah melakukan uji stasioneritas data untuk mengetahui apakah data perlu didefferenncing atau tidak. Hasil uji Stasioneritas dengan uji ADF ditampilkan dalam tabel berikut :

\begin{tabular}{|l|l|l|l|l|}
\hline $\begin{array}{l}\text { Statist } \\
\text { ic }\end{array}$ & $\begin{array}{l}\text { Kresna } \\
\text { Flexima }\end{array}$ & $\begin{array}{l}\text { Pratama } \\
\text { berimbang }\end{array}$ & $\begin{array}{l}\text { Nikko } \\
\text { BUMN } \\
\text { plus }\end{array}$ & $\begin{array}{l}\text { SAM } \\
\text { Syariah } \\
\text { Berimban } \\
\text { g }\end{array}$ \\
\hline $\begin{array}{l}\text { Proba } \\
\text { bilitas }\end{array}$ & 0,0000 & 0,0000 & 0,0000 & 0,0000 \\
\hline $\begin{array}{l}\text { Nilai } \\
\text { ADF }\end{array}$ & 17,0565 & 15,5724 & 14,4346 & 14,07765 \\
\hline $\begin{array}{l}\text { Mac } \\
\text { Kinno } \\
\text { n 5\% }\end{array}$ & 2,87329 & 2,87334 & 2,87329 & 2,873289 \\
\hline $\begin{array}{l}\text { kesim } \\
\text { pulan }\end{array}$ & $\begin{array}{l}\text { Prob }<\alpha \\
\text { ADF }>5 \% \\
\text { Stasioner }\end{array}$ & $\begin{array}{l}\text { Prob }<\alpha \\
\text { ADF }>5 \% \\
\text { Stasioner }\end{array}$ & $\begin{array}{l}\text { Prob }<\alpha \\
\text { ADF }>5 \% \\
\text { Stasioner }\end{array}$ & $\begin{array}{l}\text { Prob }<\alpha \\
\text { ADF }>5 \% \\
\text { Stasioner }\end{array}$ \\
\hline
\end{tabular}

Dari hasil diatas dapat disimpulkan bahwa semua return dari aset tidak mempunyai unit root atau memenuhi asumsi stasioneritas. Dengan demikian analisis dapat dilanjutkan ke proses selanjutnya yaitu membentuk portofolio yang optimal.

\section{Portofolio Optimal}

Portofolio yang optimal akan dibentuk dengan metode Markowitz. Produk reksadana yang akan dibentuk adalah Kresna Flexima besutan PT Kresna Asset Management, Pratama berimbang besutan PT Pratama Capital Asset Management, Nikko BUMN Plus yang dikelola PT Nikko Asset Management dan SAM Syariah Berimbang milik PT Samuel Asset Management. Metode Markowitz diperoleh portofolio sebagai berikut

\begin{tabular}{|l|l|l|l|l|l|l|} 
Statistic & $\begin{array}{l}\text { Kresna } \\
\text { Flexima }\end{array}$ & $\begin{array}{l}\text { Pratama } \\
\text { berimban } \\
\mathrm{g}\end{array}$ & $\begin{array}{l}\text { Nikko } \\
\text { BUMN } \\
\text { plus }\end{array}$ & $\begin{array}{l}\text { SAM } \\
\text { Syariah } \\
\text { Berimba } \\
\text { ng }\end{array}$ & Kresna fleksima & Proporsi \\
Varian & 0,402911 & 0,003231 & $\begin{array}{l}7,69672 \\
\text { E-05 }\end{array}$ & $\begin{array}{l}0,000112 \\
839\end{array}$ & Pratama Berimbang & $0 \%$ \\
\hline $\begin{array}{l}\text { Std } \\
\text { Deviasi }\end{array}$ & 0,634753 & 0,056839 & $\begin{array}{l}0,008773 \\
097\end{array}$ & $\begin{array}{l}0,010622 \\
563\end{array}$ & Nikko BUMN Plus & $80 \%$ \\
\hline
\end{tabular}


\begin{tabular}{l|l} 
Sam Syariah Berimbang & $20 \%$
\end{tabular}

\section{Uji heteroscedastic}

Langkah selanjutnya dilakukan pengujian heteroscedastic. Uji ini digunakan untuk mengetahui apakah ada conditional variance (Winarno, 2009), uji heteroscedastic dilakukan dengan uji White menggunakan bantuan eviews dan hasilnya nilai Obs * RSquared 244,00 dan nilai p_value 0,0000 ( lebih kecil dari $\alpha=5 \%$ ) maka dapat disimpulkan bahwa data tersebut bersifat heteroskedasatis. Dan $\sigma$ dihitung dengan metode EWMA sebesar 0,08308.

\section{Uji Normalitas}

Portofolio yang dibentuk selanjutnya diuji asumsi normalitasnya untuk mengetahui apakah portofolio yang dibentuk berdistribusi normal apa tidak. Dengan uji Jaque - Bera $>$ 2 dan p_value $<0,005$ maka diperoleh kalau portofolio tidak berdistribusi Normal. Karena distribusi tidak normal, maka maka nilai $\alpha$ untuk menghitung VaR harus dihitung dengan pendekatan Cornish Fisher Expansion. Dengan pendekatan Cornish Fisher Expansion diperoleh nilai $\alpha$ sebesar 3,15598 untuk tingkat kepercayaan $95 \%$.

\section{Value at Risk}

Dengan $\sigma$ sebesar 0,08308 dan $\alpha$ sebesar 3,15598 maka diperoleh nilai $\mathrm{VaR}$ berdasarkan rumus (2.6) sebesar 0,26221001 untuk setiap Rp.1,00 portofolio. Artinya kemungkinan kerugian terburuk yang akan dialami investor sebesar 0,26221001 atau $26 \%$. Dalam backtesting terhadap kerugian yang terjadi dengan menggunakan uji kupic maka diperoleh hasil penyimpangan sebesar nol (tidak ada penyimpangan) dan nilai $\hat{\alpha}$ sebesar 0,9999 lebih besar daripada tingkat kepercayaan 0,95 maka dapat disimpulkan bahwa nilai VaR bisa diterima.

VaR Komponen (CVaR)
VaR Komponen adalah kontribusi risiko masing-masing komponen terhadap risiko portofolio, dari hasil VaR sebelumnya maka dihitung $\mathrm{CvaR}$ dan Backtesting seperti berikut :

\begin{tabular}{|l|l|l|}
\hline & Kresna & Nikko \\
\hline $\begin{array}{l}\text { Prob Uji white } \\
\text { heteroskedastic }\end{array}$ & 0,00000 & 0,001024 \\
\hline Obs* R-Squared & 226,0780 & 13,76823 \\
\hline $\begin{array}{l}\text { Kesimpulan Uji } \\
\text { heteroskedastic }\end{array}$ & $\begin{array}{l}\text { Heteroskedast } \\
\text { ics }\end{array}$ & $\begin{array}{l}\text { Heteroskedast } \\
\text { ic }\end{array}$ \\
\hline Nilai $\sigma$ & 0,415180518 & 0,0035441 \\
\hline Jarque Bera & 569160,5 & 84,72628 \\
\hline Prob & 0,000000 & 0,00000 \\
\hline $\begin{array}{l}\text { Kesimpulan Uji } \\
\text { Normal }\end{array}$ & Tidak Normal & Tidak Normal \\
\hline Nilai $\alpha$ & $-3,21729$ & 1,655483 \\
\hline Bobot & $20 \%$ & $80 \%$ \\
\hline $\begin{array}{l}\text { Value at Risk } \\
\text { komponen }\end{array}$ & 0,267151431 & 0,046937 \\
\hline$\hat{\alpha}$ & $0,99963<0,05$ & $0<0,05$ \\
\hline kupic & diterima & ditolak \\
\hline \multicolumn{2}{|l|}{ Dari tabel } & diatas dapat \\
ditunjuk
\end{tabular}

Dari tabel diatas dapat ditunjukkan bahwa nilai CvaR untuk reksadana campuran Kresna Flexima adalah 0,267151431 dan untuk Nikko BUMN Plus adalah sebesar 0,0046937. Namun setelah divalidasi, nilai VaR dari Nikko BUMN plus tidak lolos uji kipiec, artinya nilai VaR untuk Nikko BUMN kurang Valid jika digunakan metode pendekatan EWMA. Nilai CvaR digunakan untuk mengetahui tingkat kontribusi masingmasing tingkat resiko terhadap resiko portofolio. Jadi bisa dikatakan untuk reksadana Kressna Flexima memberi kontribusi VaR sebesar 0,267151431 terhada nilai VaR portofolio. Reksadana Nikko BUMN Plus tidak bisa disimpulkan untuk analisis tingkat risiko dengan metode EWMA karena hasil ujinya ternyata tidak signifikan.

\section{KESIMPULAN}

Value at Risk (VaR) adalah salah satu alat ukur untuk menghitung risiko pasar. VaR menjadi alat ukur paling penting dalam manajemen risiko. Penelitian ini memberikan gambaran resiko terburuk yang mungkin 
akan dihadapi investor reksadana campuran di Indonesia. Reksadana yang akan dianalisis adalah Kresna Flexima besutan PT Kresna Asset Management, Pratama berimbang besutan PT Pratama Capital Asset Management, Nikko BUMN Plus yang dikelola PT Nikko Asset Management dan SAM Syariah Berimbang milik PT Samuel Asset Management. Dari 4 reksadana campuran yang diusulkan berdasarkan kinerjanya selama 3 tahun terakhir versi majalah http://market.bisnis.com hanya 2 reksadana yang digunakan analisis untuk mendapatkan portofolio yang optimal bedasarkan metode Markowitz. Metode pencarian VaR yang digunakan adalah metode EWMA karena dalam perhitungan ditemukan adanya conditional variance. Dengan tingkat keperayaan 95\% dan decay factor sesuai dengan yang diusulkan Risk Metrics sebesar 0,94 untuk data harian maka diperoleh nilai VaR sebesar 0,26221011. Artinya kerugian maksimal yang mungkin akan diterima investor sebesar $26,22 \%$ jika investor melakukan investasi dalam aset yang dianjurkan oleh portofolio optimal sesuai metode Markowitz yaitu 20\% di reksadana campuran Kresna Flexima dan $80 \%$ di reksadana campuran Nikko BUMN Pluss. Tingkat risiko $\mathrm{VaR}$ ini sudah divalidasi dengan uji kupiec. Dengan diketahui kemungkinan tingkat risiko tersebut, diharapkan investor bisa mengelola risiko yang mungkin bisa terjadi.

Perhitungan VaR harian masing-masing Reksadana pendukung portofolio (CVaR) dilakukan sebagai pembanding nilai $\mathrm{VaR}$ portofolio optimal yang telah dicari. Nilai CvaR ini digunakan untuk mengetahui tingkat kontribusi masing-masing tingkat resiko terhadap resiko portofolio. Jadi bisa dikatakan untuk reksadana Kressna Flexima memberi kontribusi VaR sebesar 0,267151431 terhada nilai VaR portofolio. Reksadana Nikko BUMN Plus tidak bisa disimpulkan untuk analisis tingkat risiko dengan metode EWMA karena hasil uji validasinya ternyata tidak signifikan. Jadi dengan metode EWMA hanya reksadana Kressna Flexima yang mempengaruhi VaR total.

Dalam penelitian ini hanya difokuskan pada reksadana dengan kinerja terbaik selama 3 tahun terakhir versi market.bisnis.com dengan decay factor sesuai dengan yang diusulkan Risk Metrics dengan metode EWMA. Pada kenyataanya tingkat ketahanan investor berbeda-berda terhadap faktor risiko. Untuk itu diharapkan penelitian selanjutnya bisa melengkapi penelitian ini dengan fokus yang belum dilakukan dalam penelitian ini misalnya dengan pengoptimalan decay factor atau dengan membandingkan reksadana campuran dengan reksadana yang lain. Metode EWMA tidak bisa digunakan untuk mencari komponen VaR untuk reksadana Kressna Flexima, untuk penelitian selanjutnya bisa dicari dengan metode lain agar semua kendala yang terjadi bisa terjawab sesuai dengan teorinya masing-masing.

\section{DAFTAR PUSTAKA}

Astria, Riendy. 2015, Favorit Investor, Reksa Dana Campuran Bisa Jadi Pilihan Investasi, http://market.bisnis.com/read/201501 20/92/393166/favorit-investor-reksadana-campuran-bisa-jadi-pilihaninvestasi, diakses 28 Maret 2016.

Buchdadi, Agung D. 2008, Perhitungan Value at Risk Portofolio Optimum Saham Perusahaan Bebasis Syariah dengan Pendekatan EWMA, Jurnal Akuntansi dan Keuangan Indonesia, Desember 2008, Vol. 5, No. 2, Hal. $182-201$ 
Down, Kevin, 2002, Measuring Market Risk, John Willey \& Sons L.td. England.

Fitriyani, Yuli, 2015 "Penggabungan Risiko Likuiditas Endogen ke Dalam Value at Risk", Tesis, Universitas Gadjah Mada, Yogyakarta.

Fuss, Roland., Dieter G. Kaiser and Zeno Adams, 2007, Value at risk, GARCH modelling and the forecasting of hedge fund return volatility, Journal of Derivatives \& Hedge Funds Volume 13 Number 12007.

Hartono, Jogiyanto, 2014, Teori dan Praktik Portofolio dengan Excel, Salemba Empat, Jakarta

Hikmah, Sofi Faiqotul, 2015, Analisis Risiko Investasi Pada Reksadana Syariah Dengan Menggunakan Pendekatan Var (Value At Risk), Jurnal Hukum Islam, Ekonomi Dan Bisnis Vol.1. No.1. Januari 2015, ISSN 2460-0083.
Jorion, Philippe. Value at Risk 2nd New York : McGraw-Hill, 2001

Laila, Farah R, 2010, Perhitungan Value at Risk Indeks Saham Syariah Menggunakan Model Volatilitas ARCH-GARCH dalam Kelompok Jakarta Islamic Index, Skripsi Program Studi Matematika UIN Syarif Hidayatullah Jakarta.

Morgan, JP., and Reuters, 1995, Risk Metrics Technical Document, Morgan Guaranty Trust Company, NewYork.

Pratiwi, Noviana, 2015 , Estimasi Penyesuaian Likuiditas Terhadap Value At Risk Dari Data Historis, Jurnal Teknologi Technoscientia, ISSN: 1979-8415, Vol. 8 No. 1 Agustus 2015, Yogyakarta

Rosadi, D., 2009, Manajemen Risiko Kuantitatif, UGM, Yogyakrata.

Winarno, W Wahyu, 2009, Analisis Ekonometrika dan Statistika dengan Eviews, UPP STIM YKPN, Yogyakarta 